\title{
Patrimônio ambiental urbano, cidade e memória: uma dimensão política da preservação cultural na década de 1980
}

Urban environmental heritage, city and memory: the political dimension of cultural conservation in the 1980s

https://doi.org/10.1590/1982-02672020v28d2e28

\author{
ANDRÉA DE OLIVEIRA TOURINHO' \\ https://orcid.org/0000-0002-9167-9762 \\ Universidade São Judas Tadeu / São Paulo, SP, Brasil
}

\section{MARLY RODRIGUES 2}

http:/ / orcid.org/0000-0002-0433-4468

Memórias Assessoria e Projetos / São Paulo, SP, Brasil

RESUMO: A partir da experiência de São Paulo, pretende-se abordar as relações entre cidade e memória, traduzidas no conceito de patrimônio ambiental urbano, e as políticas de preservação na década de 1980. Em um momento de ebulição das problemáticas sociais, acentuava-se a importância da reforma urbana e da gestão democrática da cidade, ao mesmo tempo em que o campo do patrimônio cultural se redefinia como memória. Na década de 1980, novas formas de abordagem do patrimônio cultural lançaram um outro olhar sobre as relações entre cidade, memória e sociedade. A base conceitual dessas experiências encontrava-se nas ideias desenvolvidas nos anos 1970, quando setores da sociedade passaram a se preocupar com os efeitos negativos dos processos da industrialização, metropolização e renovação urbana sobre a qualidade de vida na cidade. $\bigcirc$ conceito de patrimônio ambiental urbano encontrava-se no cerne daquelas ideias, gestado no campo do planejamento econômico e territorial, com a contribuição do campo da preservação do patrimônio, no contexto dos governos militares. Em São Paulo, o conceito de patrimônio ambiental urbano passa da política de planejamento, nos
1. Doutora em Arquitetura e Urbanismo pela Faculdade de Arquitetura e Urbanismo da Universidade de São Paulo (FAU-USP), mestra em Estética e Teoria das Artes pela Universidad Autónoma de Madrid, e Arquiteta e Urbanista pela Universidade Mackenzie. Atualmente, é docente do Programa de Pós-Graduação Stricto Sensu e do Curso de Graduação em Arquitetura e Urbanismo da Universidade São Judas Tadeu. Trabalhou com políticas públicas na Prefeitura Municipal de São Paulo, nas áreas de preservação do patrimônio e de desenvolvimento urbano. Líder do Grupo de Pesquisa "Patrimônio Cultural e Urbanismo: discursos e práticas", certificado pelo CNPq. E-mail: <drea.tourinho@ig.com.br>.

2. Doutora em História. Especializou-se no curso Architectural Conservation no Iccrom - Unesco. Foi historiógrafa no Condephaat-SEC e exerceu no Condephaat-SEC e no Iphan-SP coordenadorias técnicas. Lecionou no Curso de Arquitetura e Urbanismo da 
FAAP e atualmente ministra cursos no CPC-USP, CPFP-Sesc e exerce atividades de consultoria e assessoria em Patrimônio Cultural, História e Memória. E-mail: <marly@mem.com.br>. anos 1970, para a política estadual e municipal de preservação do patrimônio na década de 1980. Nos órgãos estadual e municipal de preservação em São Paulo, as preocupações que então se delineavam foram traduzidas em experiências inovadoras de aproximação com o campo do planejamento, de valorização das memórias sociais e de interação com a sociedade.

PALAVRAS-CHAVE: Patrimônio cultural. Planejamento urbano. Políticas públicas.

ABSTRACT: Out of São Paulo's experience, this paper intends to address the relations between city and memory, translated into the concept of urban environmental heritage, and conservation policies in the 1980s. At a boiling time of social problems, the emphasis was put on the urban reform importance, and the democratic management of the city, while the field of cultural heritage redefined itself as memory. In the 1980s, new ways of approaching cultural heritage cast other look at the relationships between city, memory and society. The conceptual basis of these experiences was found in the ideas developed in the 1970s, during the authoritarian period, when sectors of society began to worry about the negative effects of the processes of industrialization, metropolization and urban renewal on the quality of life in the city. Landscape and environment entered into the vocabulary of urban public policies and cultural heritage. The concept of urban environmental heritage was at the heart of those ideas, developed in the field of economic and territorial planning, with the contribution of the heritage conservation field, within the context of military governments. In São Paulo, the concept of urban environmental heritage shifts from the planning policy in the 1970s to the state and municipal policy of heritage conservation in the 1980s. In state and municipal conservation bodies in São Paulo, these issues will translate into innovative experiences of approaching the field of planning, valuing social memories and interacting with society.

KEYWORDS: Cultural heritage. Urban planning. Public policies. 


\section{INTRODUÇÃO}

ano de 1989, quando ocorreu a queda do Muro de Berlim, pode ser tomado como marco final de um período histórico - a modernidade - que se iniciara havia dois séculos, no contexto da Revolução Francesa. Desde então assentado na ideia de progresso, o ocidente passara a confiar na História como a narrativa da evolução humana, no amanhã sempre melhor que o hoje e no futuro como o tempo de realização de utopias.

Após cerca de dois séculos, a quebra dessa relação entre sociedade e tempo histórico repercutiria sobre os sentidos atribuídos a duas narrativas do passado, ambas criadas no período da modernidade: a história e o patrimônio. Aliados à memória, história e patrimônio passaram a constituir elos de revalorização do presente e de reconhecimento e criação de novos lugares sociais.

Em escala mundial, estava então em curso um fenômeno multidimensional sintetizado na palavra globalização; nela se expressa o rompimento com modelos de civilização até então adotados, o que inclui uma certa tensão entre universalidade e particularidade da experiência humana; o espaço entre esses polos tornou-se lugar de exposição da diversidade social e cultural, e de expressão da busca de identidades grupais e locais.

Nesse contexto, verifica-se, desde os anos de 1980, um considerável crescimento da demanda por proteção pública de bens culturais, o que resultou na diversificação dos bens tutelados pelo Estado. Diante da inexistência ou insuficiência de políticas públicas promotoras da preservação de bens e práticas culturais, em períodos mais recentes vêm se verificando, especialmente nos grandes centros urbanos, movimentos independentes de valorização de marcos, lugares e práticas, constituídos pelas próprias comunidades, organizadas em torno da preservação de suas referências culturais.

Do ponto de vista institucional, a tensão universalidade/particularidade parece estar presente na criação da categoria "patrimônio mundial", consagrada na Convenção sobre a salvaguarda do patrimônio mundial, cultural e natural, também conhecida como Convenção de Paris, documento resultante da Conferência Geral da Unesco realizada em Paris, no ano de 1972. Nele, o acelerado "empobrecimento nefasto do patrimônio de todos os povos do mundo" é o principal argumento justificador da necessidade de proteção internacional e nacional de bens culturais, a partir do qual se reitera a obrigação de cada Estado identificar, proteger, conservar, valorizar e transmitir às futuras gerações os patrimônios cultural e natural, partindo de uma política definida 
3. Cury (2000, p. 177-181).

4. Ibid., p. 13 e 17.

5. Ibid., p. 52-53.

6. A Conferência Geral da Unesco, 9a Sessão, foi realizada em Nova Déli e tratou dos princípios internacionais a serem aplicados nas pesquisas arqueológicas; ibid., p. 81-90. em função da vida da coletividade e que vise "integrar a proteção desse patrimônio nos programas de planejamento geral". ${ }^{3}$

\section{A GLOBALIZAÇÃO DO PATRIMÔNIO E AS CIDADES}

No universo da prática patrimonialista, a criação da categoria "patrimônio mundial" assemelha-se ao derradeiro momento da prevalência da concepção do patrimônio como um conjunto de representações da nação. Em tempos de globalização, um dos componentes dessa representação, a territorialidade, tem sido simbolicamente dissolvida pelas possibilidades de comunicação oferecidas por tecnologias que, simultaneamente, promovem o compartilhamento de fazeres, de formas de ser, possibilitam o rompimento dos limites geográficos e desnudam a complexidade e as variações possíveis entre a homogeneização e a diversificação da cultura globalizada.

A construção de uma visão universal de patrimônio se iniciara com a Carta de Atenas de 1931, conjunto de recomendações "concernentes à proteção de monumentos" que também apontou a "utilidade de uma documentação internacional." 4 Dois anos depois, a Carta de Atenas do Congresso Internacional de Arquitetura Moderna (Ciam) trataria das relações entre a salubridade do ambiente urbano e a qualidade da vida na cidade moderna, atribuindo ao patrimônio - nos seus itens 65 a 67 - o significado de conjunto de "testemunhos preciosos do passado" de "valor histórico e sentimental" ou "virtude plástica", a ser salvaguardado como "expressão de uma cultura anterior e se corresponderem a um interesse geral $[\ldots]$ ", e desde que sua conservação não acarretasse "o sacrifício de populações mantidas em condições insalubres [... [". ${ }^{\prime 5}$

A Segunda Guerra Mundial interromperia a construção dessa visão universal de patrimônio, e as cartas e recomendações, que sintetizariam o avanço das discussões conceituais e apontariam diretrizes de procedimentos técnicos, foram retomadas apenas em 1956, ${ }^{6}$ tendo como núcleo promotor a Organização das Nações Unidas para a Educação, a Ciência e a Cultura (Unesco), criada em 1945.

Por meio dos documentos internacionais é possível acompanhar a ampliação do conceito de patrimônio e a construção de um conhecimento específico e universal nem sempre passível de ser refletido nas ações de preservação locais.

A Conferência Geral da Unesco, realizada em Paris, no ano de 1962, tratou de paisagens e sítios, neles reconhecendo valores científicos, econômicos e estéticos, o que aponta a ampliação da abrangência do termo patrimônio, até então restrito 
ao campo da história e da arte, para o amplo campo da cultura. No seu documento, Recomendação relativa à salvaguarda da beleza e do caráter das paisagens e sítios, também se delineia o patrimônio como parte das condições contemporâneas da vida coletiva e do "rápido desenvolvimento do progresso técnico".?

Então, a internacionalização do patrimônio também se apoiava em instituições específicas, como o Conselho Internacional de Museus (Icom), criado em 1945, e o Centro Internacional para o Estudo da Preservação e Restauração de Bens Culturais (Iccrom), fundado em 1956, este voltado ao estudo e à formação de pessoal especializado; posteriormente, em 1965, criou-se o Conselho Internacional de Monumentos e Sítios (lcomos).

Desde a década de 1950, vinha se ampliando a diversidade dos bens considerados passíveis de serem tutelados pelo Estado, com a inclusão sucessiva de vestígios arqueológicos, paisagens e o ambiente humano. ${ }^{8} \mathrm{Em}$ 1964, a Carta de Veneza rompe a restrita noção de monumentalidade, à essa acrescendo as "obras modestas" de "significação cultural". 9 Em 1972, a Conferência Geral da Unesco consagra o uso de duas novas categorias de classificação, "patrimônio natural" e "patrimônio cultural" em lugar de "patrimônio histórico e artístico". Ampliou-se também o entendimento de "bens imóveis" com classificações baseadas em características particulares, como "patrimônio industrial", que seria consagrado em 1973, com a criação do Comitê Internacional para a Conservação do Patrimônio Industrial (Ticcih).

Paralelamente a essa expansão, cresciam as dificuldades financeiras de conservação dos bens, especialmente nos países "em desenvolvimento", como os da América Latina. A percepção da necessidade de inserção do patrimônio na dinâmica econômica como forma de garantir sua conservação vinha se delineando desde a década de 1950. Aos poucos revelou-se a impossibilidade de mantê-lo acima das disputas e contradições inerentes à vida em sociedade, apenas como objeto de fruição, documento do passado, caminho linear entre os tempos e herança a ser legada para as gerações futuras.

Em 1967, nas Normas de Quito, ${ }^{10}$ resultante da reunião promovida pela Organização dos Estados Americanos (OEA), organismo regional criado em 1948, aborda-se a contradição entre a riqueza da herança cultural e as ameaças à sua integridade física e propõe-se o aproveitamento econômico do patrimônio por meio do turismo, meio também apontado como promotor das melhorias socioeconômicas para a sociedade.

A adoção da finalidade turística fez crescer a ênfase na preservação e/ou revitalização de centros históricos na América Latina, como se pode verificar pela constante menção a eles em documentos de encontros realizados
7. Ibid., p. 82.

8. O que pode ser verificado na Conferência Geral da Unesco, Nova Déli, dez. 1956; na Conferência Geral da Unesco, Paris, dez. 1962; e na Declaração de Estocolmo, Organização das Nações Unidas para o Meio Ambiente, jun. 1972. Cf. Cury (2000). Em aula ministrada em São Paulo, no ano de 1974, Hugues de Varine-Bohan (s. d.) apontou a variedade e mutabilidade das definições de patrimônio cultural e o definiu como composto pela natureza, o meio ambiente, aspectos intangíveis, como as técnicas, saberes e fazeres, além de artefatos e objetos. No Brasil, a tutela do Estado sobre bens intangíveis data do ano de 2000 , quando entra em vigor o Decreto Federal no 3.551.

9. Carta de Veneza, Definições. Cury (2000, p. 91-95).

10. Normas de Quito. Reunião sobre a conservação e utilização de monumentos e sítios de interesse histórico e artístico. Organização dos Estados Americanos, OEA, nov./dez. 1967. Cury (2000, p. 105-122). 
11. Documento do I Seminário interamericano sobre experiências na conservação e restauração do patrimônio monumental dos períodos colonial e republicano, realizado na República Dominicana, em dezembro de 1974. D-Propostas Operativas-7. Cury (2000, p. 197).

12. Em 1966, o Decreto-Lei no 55 criou a Empresa Brasileira de Turismo e o Conselho Nacional de Turismo, que definiu a política nacional para o setor. No ano de 2003, foi criado o Ministério do Turismo. O Compromisso de Salvador resultou do II Encontro de Governadores para Preservação do $\mathrm{Pa}$ trimônio Histórico, Artístico, Arqueológico e Natural do Brasil, promovido pelo $\mathrm{Mi}$ nistério da Educação e Cultura-Iphan, em out. de 1971. Cury (2000, p. 143-146).

13. Carta do Restauro, abril de 1972. Ministério da Instrução Pública, Governo da Itália, Anexo D. Cury (2000, p. 166-169).

14. Efetivamente, o tema do IX Ciam, que ocorreu em Aix-en-Provence (França), em 1953, foi a "Carta do Habitat”, proposta por uma nova geração de arquitetos que criticava as posturas funcionalistas consolidadas até então, e colocava a necessidade de se discutir as noções de ambiente e habitat na construção da cidade.

15. Cury (op. cit., p. 180).

16. Portaria Miniplan $050 / 73$, que criou efetivamente o Programa Integrado de Reconstrução das Cidades Históricas do Nordeste, com sua Utilização para Fins Turísticos.

17. Cf. Corrêa (2015). nas décadas de 1970, como o que resultou na Resolução de São Domingos ${ }^{11}$ e no Compromisso de Salvador. Este, referente a medidas do governo para melhor preservação do patrimônio brasileiro, recomendava a colaboração de órgãos governamentais de financiamento de modo a promover o desenvolvimento da indústria turística tendo em vista "a valorização, utilização e divulgação dos bens naturais e de valor cultural especialmente protegidos por lei". ${ }^{12}$

Ao mesmo tempo, porém, no campo internacional cresciam as críticas ao tratamento quase sempre adotado para a preservação da área da cidade em que se concentram bens de valor histórico-cultural, o que, em geral, resultava no isolamento entre os centros históricos e as demais áreas urbanas, desconectando-as de melhoramentos e criando problemas, como os de mobilidade, para o conjunto da cidade. Já em 1972, a Carta do Restauro, documento italiano, propôs que a conservação dos centros históricos fosse tomada como fator de requalificação urbana e territorial, o que implicava inúmeros aspectos, desde a reordenação viária até a renovação interna das edificações, de modo a adaptálas aos usos previstos. ${ }^{13}$

Não são menos importantes, nesse debate, os novos posicionamentos críticos que, desde o final da Segunda Guerra Mundial, consolidavam-se em relação à visão funcionalista de cidade que até então tinha predominado no planejamento e na intervenção urbana, e introduziam a necessidade de se relacionar ambiente e habitat, entendido como condições de habitabilidade mais amplas do que simplesmente a habitação, no contexto urbano. ${ }^{14}$

A Convenção de Paris, também elaborada em 1972, no encontro sobre a salvaguarda do patrimônio mundial, cultural e natural, recomendava que "na medida do possível, e nas condições apropriadas a cada país" entre outras medidas, se adotasse "uma política geral que vise a dar ao patrimônio cultural e natural uma função na vida da coletividade e a integrar a proteção desse patrimônio nos programas de planejamento geral". ${ }^{15} \mathrm{Em}$ "planejamento geral" cabem diferentes abrangências, mas, fossem elas quais fossem, abria-se a perspectiva de rompimento com a ideia de exclusividade do turismo como via de inserção do patrimônio na dinâmica econômica de cada país.

No Brasil, o Ministério do Planejamento atenderia a essa recomendação ao criar um grupo especial de trabalho constituído por membros desse ministério e dos ministérios da Indústria e Comércio, do Interior, e da Educação e Cultura, representado pelo Iphan, para a criação do Programa de Cidades Históricas (PCH), cujo início efetivo se deu no ano seguinte. ${ }^{16} \mathrm{O}$ objeto era a preservação de bens tombados, e sua sustentação econômica seria por meio de atividades turísticas. ${ }^{17}$ 
Porém, a conceituação relativa ao tratamento dos sítios históricos, consideradas suas relações com o conjunto da cidade, só seria publicamente discutida no país em 1987, por ocasião da realização do $1^{\circ}$ Seminário Brasileiro para Preservação e Revitalização de Centros Históricos, cujo documento final foi a Carta de Petrópolis. ${ }^{18}$

país atravessava então um período de expectativas e renovação decorrentes do fim do período ditatorial e da discussão da nova carta constitucional, documento basilar da reorganização do sistema democrático.

A Carta de Petrópolis reflete esse clima, explicitando a potencialidade do patrimônio na consolidação da cidadania, e, como objetivo último da preservação, a "implementação da qualidade de vida"; o planejamento foi nela definido como "uma das formas de pleno exercício da cidadania" e a ampla perspectiva adotada no documento era a "reapropriação política do espaço urbano pelo cidadão". ${ }^{19}$

documento renomeou o centro histórico como "sitio histórico urbano", entendido como "área crítica", "não por oposição a espaços não-históricos da cidade, uma vez que toda a cidade é um organismo histórico", e apontou a sensível questão de uso do patrimônio situado nos sítios históricos urbanos: sua "função primordial" deveria ser a moradia, sem exclusão de outros usos, não apenas culturais, mas, sobretudo, os atinentes "aos universos do trabalho e do cotidiano". ${ }^{20}$

A cidade contemporânea, esse complexo artefato de grande significado como lugar de expressão de conflitos e de construção de memórias, passara a ganhar maior espaço nas discussões internacionais na década de 1970, ao mesmo tempo em que diversos estudos, entre eles o pioneiro Direito à Cidade, de Henri Lefebvre, publicado em 1968, incentivavam discussões e críticas aos parâmetros de planejamento urbano e ao papel das cidades na sociedade contemporânea. ${ }^{21}$

Nessa perspectiva, da reunião do Conselho da Europa, realizada em outubro de 1975, na cidade de Amsterdã, resultaram a Declaração de Amsterdã e a Carta Europeia do Patrimônio Arquitetônico, também nomeada Manifesto de Amsterdã, documentos construídos em torno do conceito de "conservação integrada", cuja definição vinha sendo gestada a partir das críticas sobre o tratamento de centros históricos. ${ }^{22}$ Ambos orientaram-se pela perspectiva da conservação do patrimônio arquitetônico com o "objetivo maior do planejamento das áreas urbanas e do planejamento físico-territorial". ${ }^{23}$ A Declaração de Amsterdã aponta como indispensável um "diálogo permanente entre os conservadores e planejadores" e como essencial a "descentralização e o reconhecimento das culturas locais", bem como o "apoio da opinião pública". ${ }^{24}$

Essa posição, que envolve a utilização do patrimônio como parte do atendimento de demandas sociais por melhor qualidade de vida, não lograria
18. Cury (2000, p. 285-287).

19. Carta de Petrópolis, 1987. Cury (2000, p. 286).

20. Cury (2000, p. 286).

21. Além de Henri Lefebvre, lembramos Manuel Castells e David Harvey.

22. Cf. Cesari (1980). O livro reúne textos apresentados no 6o Simpósio Europeu sobre o Patrimônio Arquitetônico, realizado pelo Conselho da Europa, em 1978, na cidade de Ferrara.

23. Conselho da Europa. Declaração de Amsterdã, out. 1975. Cury (2000, p. 200).

24. Conselho da Europa. Declaração de Amsterdã, out. 1975. Cury (2000, p. 202-204) 
25. ONU. Declaração Universal dos Direitos Humanos. 1948. Art. 27. Direitos culturais aparecem pela primeira vez em 1917, na Constituição Política dos Estados Unidos Mexicanos. Cf. Cunha Filho; Botelho; Severino (2018).

26. Chaui (2006 apud Pazzini; Sparemberger, 2014, p. 4534).

27. O direito à cultura é garantido na Constituição $\mathrm{Fe}$ deral de 1988, Art. 215: "O Estado garantirá a todos o pleno exercício dos direitos culturais e acesso às fontes da cultura nacional, e apoiará e incentivará a valorização e a difusão das manifestações culturais" impor-se como parte das políticas de preservação no Brasil. Contudo, aceleravamse as transformações decorrentes da globalização, processo acentuado na década de 1980, quando o país vivia o período de redemocratização, o que acarretou mudanças consideráveis no campo dos direitos sociais. É na confluência desses processos - globalização, democratização e conquista de direitos sociais - que se elucidam os sentidos dos avanços e limites da prática de construção do patrimônio enquanto vetor da memória social.

\section{DIREITOS: RETRAÇANDO LUGARES SOCIAIS}

Entre 1964 e 1988, evidenciou-se, por parte dos governantes brasileiros, a desconsideração de muitos tópicos da Declaração Universal de Direitos Humanos, documento da Organização das Nações Unidas (ONU), publicado em 1948. Esse possibilitara internacionalizar a proteção aos direitos de todo e qualquer indivíduo, entre os quais o de tomar parte na vida cultural e usufruir dos benefícios dela decorrentes. ${ }^{25}$

Tomar parte da vida cultural significa ter acesso à experiência humana, quer a herdada, quer a contemporânea, que acrescenta, à primeira, novas vivências individuais e coletivas. A cultura, observa Chaui, é o modo pelo qual "os humanos se humanizam e, pelo trabalho, desnaturalizam a natureza por meio de práticas que criam a existência social, econômica, política, religiosa, intelectual e artística". ${ }^{26}$ Existências essas não apenas materiais, mas também simbólicas, e que constituem o patrimônio cultural, conjunto representativo dos valores, costumes e tradições de grupos sociais e parte de sua memória.

A memória é, portanto, parte constitutiva da cultura e tem relação direta com sua produção; por isso é essencial à qualidade de vida individual e coletiva, uma vez que mobiliza subjetividades, desenha identidades e identificações culturais, acentuando tanto o sentimento de pertença, de afinidade entre sujeito, sociedade e lugar, como a possibilidade de convivência com a diversidade de sujeitos e de práticas culturais.

O direito à cultura inclui o direito à memória, construção social dinâmica, ampla, constituída por diversos vetores, entre eles o do patrimônio cultural. ${ }^{27}$ Essa complexidade dificulta o estabelecimento de limites jurídicos de defesa dos direitos culturais, em parte amparada com a definição de "direitos culturais operacionalizáveis, ou seja, que podem ser materializados ou violados e, neste 
caso, juridicamente recompostos [...]": os "das artes, o da memória coletiva e o do fluxo dos saberes, fazeres e viveres". ${ }^{28}$

Do ponto de vista jurídico, os direitos humanos são também compreendidos como indivisíveis e entrelaçados. Marchesan ${ }^{29}$ nos oferece como exemplo a manutenção do meio ambiente: o direito ao meio ambiente sadio não se restringe apenas à dimensão natural, mas se projeta nas relações sociais, de trabalho, cultura e lazer dos homens.

A compreensão da indivisibilidade dos direitos humanos, prossegue a autora, também se expressa na Constituição Federal de 1988, onde o "bem-estar" aparece relacionado a atividades diversas, como a política urbana, a ordem social e a ciência e tecnologia, a "sadia qualidade de vida" e ao meio ambiente. ${ }^{30}$ Citando Reisewitz, Marchesan observa que, ao preservar o patrimônio cultural brasileiro, o Estado está praticando uma política de preservação do meio ambiente cultural, que "é meio para garantia da qualidade de vida humana" o que faz de sua proteção, "a um só tempo, direito ambiental e direito cultural". ${ }^{31}$

De acordo com Morin e Kern, a Constituição de 1988 "assume a ideia de que somos a um só tempo conformados pela cultura e pela natureza"32 e expressa o compromisso da República com o mínimo de bem-estar espiritual e material necessário para se alcançar a dignidade humana, "para cuja densificação deve-se investir na cultura como universo referencial, e no patrimônio cultural como base de construção da identidade da nação multicultural" ${ }^{33}$

Mas, ao contrário da antiga concepção de patrimônio como um universo que, a partir dos valores histórico e artístico, representava a nação, a Constituição o define amplamente, incluindo os bens de natureza imaterial, como conjunto portador "de referência à identidade, à ação, à memória dos diferentes grupos formadores da sociedade brasileira". E dá um importante passo no caminho do exercício da responsabilidade coletiva ao integrar a comunidade como colaboradora do poder público na proteção do patrimônio cultural $^{34}$ e do patrimônio ambiental, este definido como de uso comum, essencial à sadia qualidade de vida, e também entendido como direito. ${ }^{35}$

Portador de forte carga política, o exercício de direitos culturais vem ganhando espaço desde o final da década de 1980, mas ainda há um longo caminho a percorrer para que eles se tornem definitivamente instrumentos de integração social e de completude da cidadania. Os canais necessários à participação da sociedade ainda são de difícil acesso, ou inexistem, não obstante a importância de sua participação na construção, gestão e valorização do
28. Cunha Filho; Botelho; Severino (2018, p. 29-30).

29. Marchesan (2015, p. 317).

30. Constituição de 1988 , respectivamente artigos $182,193,219$ e 225.

31. Reisewitz (2004 apud Marchesan, op. cit., p. 320).

32. Morin; Kern (2003 apud Marchesan, 2015, p. 319).

33. Marchesan (2015, p. 319).

34. Constituição de 1988 , Art. 216 e Art. $2161^{\circ}$.

35. Ibid., Art. 225: "Todos têm direito ao meio ambiente ecologicamente equilibrado [...]". 
36. Como exemplo, a Convenção de Paris, de 1972 e o Manifesto de Amsterdã, de 1975 .

37. Varine (2013, p. 11)

38. Os artigos 182 e 183 da Constituição Federal referentes à política de desenvolvimento urbano e à função social da propriedade foram regulamentados pela Lei Federal no 10.257 de 2001, o Estatuto da Cidade.

39. O conceito foi elaborado por Henri Lefebvre e apresentado em livro homônimo no ano de 1968, conforme referido anteriormente.

40. Tavolari (2016, p. 98).

41. Tavolari (2016, p. 98). patrimônio cultural venha sendo realçada em inúmeras cartas e recomendações, ${ }^{36}$ bem como seja reconhecida como essencial e faça parte da Constituição.

Os esforços para promover a maior participação das comunidades, entre outros caminhos, parecem passar pelo da superação de práticas de preservação definidas pelos valores da "alta cultura", de há muito instituídas no país, por outras, mais democráticas e já apontadas em experiências desenvolvidas pontualmente nos órgãos de preservação a partir da década de 1980.

No entender de Varine, ${ }^{37}$ o patrimônio deve estar a serviço do desenvolvimento local, uma vez que é o DNA do território e da comunidade e, como tal, se relaciona com a busca de bem-estar pretendida pela Constituição de 1988 e entendida como objetivo da defesa dos direitos culturais. $\bigcirc$ artigo 182 da Constituição de 1988 aponta para a relação das políticas de desenvolvimento urbano na concretização dos direitos culturais, uma vez que a essas cabe "ordenar o pleno desenvolvimento das funções sociais da cidade e garantir o bem-estar de seus habitantes". ${ }^{38}$

Essa perspectiva envolve a admissão da função social da propriedade que, juntamente com o "direito à cidade", 39 de acordo com Tavolari, ${ }^{40}$ foram conceitos integrados aos movimentos sociais urbanos brasileiros no período da ditadura civilmilitar. Para isso teria sido fundamental a participação de intelectuais de diferentes campos de conhecimento nesses movimentos, uma vez que, aponta a autora, se deve a eles a divulgação do conceito junto às lideranças comunitárias.

Então, a desigualdade social acentuada, entre outros fatores, pela rápida expansão das cidades brasileiras, especialmente entre 1969 e 1973, no período conhecido como "milagre brasileiro", parece ter sido outro fator essencial da integração da ideia de direito à cidade às reivindicações dos movimentos constituídos frente às diferentes formas de destituição dos direitos de cidadania, todos de alguma forma vinculados à luta pela democratização.

Em São Paulo, a pauta de direitos culturais não integrava os movimentos sociais urbanos dos setores mais populares no período da ditadura civil-militar, ainda que alguns se apoiassem na função social da propriedade e no "direito à cidade". Esses conceitos, afirma Tavolari, ${ }^{41}$ foram transmitidos por intelectuais que participavam dos movimentos por moradia e melhorias urbanas.

Mesmo entre os setores médios e altos da população, as reivindicações por direitos culturais foram pontuais, e, em geral, motivadas pela defesa da qualidade ambiental a partir de uma perspectiva ecológica, de proteção à natureza, por meio da qual se pretendia conter investimentos privados e públicos de modernização imobiliária, de alteração de áreas da cidade para o tráfego de veículos, ou de implantação de grandes estruturas de uso público. 
QUALIDADE DE VIDA E CIDADE, EM BUSCA DE UMA POLITIICA

É no momento de acentuado crescimento urbano, no período do "milagre brasileiro", relacionado à industrialização e à metropolização, que se acirrava o debate que opunha renovação e preservação nas cidades brasileiras, revelando a dualidade entre as dimensões da economia e da cultura no projeto de país então em curso. Esse crescimento urbano era visto, então, como preocupante, pois comprometia a qualidade de vida e o equilíbrio regional, afetando os modos de vida e a relação com o ambiente, o que se traduziu na criação de regiões metropolitanas na década de 1970, com o pioneirismo de São Paulo, em 1973.

O crescimento das metrópoles brasileiras tornara-se uma questão crucial, sendo objeto das diretrizes do II Plano Nacional de Desenvolvimento (II PND), para o período de 1975 a 1979, bem como do Plano Nacional de Cultura, de 1976.

Realizado no governo do general Ernesto Geisel (1974-1979), o II PND buscava dar respostas ao esgotamento do chamado "milagre econômico brasileiro" e à crise internacional do petróleo, definindo-se, em seu âmbito, as linhas gerais de um Plano Nacional de Desenvolvimento Urbano, em que se destacavam as problemáticas de um crescimento urbano desordenado, dos efeitos da poluição e da insuficiência dos recursos hídricos. A política urbana, então delineada, tinha como base estudos pioneiros sobre o desenvolvimento urbano no Brasil, realizados pelo Instituto de Planejamento Econômico e Social $\left(\right.$ lpea ${ }^{42}$ - em parceria com a Comissão Nacional de Regiões Metropolitanas e Política Urbana (CNPU), com o Instituto Brasileiro de Geografia e Estatística (IBGE) e também com o Conselho Nacional de Desenvolvimento Urbano (CNDU). Estudos realizados sob a coordenação da geógrafa Maria Adélia de Souza e do arquiteto Jorge Guilherme Francisconi, ${ }^{43}$ para a Secretaria de Planejamento da Presidência da República (Seplan/PR), "consideravam a definição de categorias espaciais (metrópoles e cidades médias), aglomerações urbanas, eixos de desenvolvimento e áreas de preservação ambiental". ${ }^{44}$ Desenvolvimento urbano e preservação ambiental eram as duas faces da mesma moeda, relacionadas ao modelo econômico brasileiro e seus impactos sobre o ambiente.

A Seplan/PR, que ditava as diretrizes nacionais de desenvolvimento urbano, também estabeleceu, durante a década de 1970, critérios que norteariam a política de preservação do patrimônio, sendo "provável que dessa aproximação entre as áreas de planejamento e preservação tenha se desenvolvido o conceito de patrimônio ambiental urbano", ${ }^{45}$ que passava a relacionar cidade, história e ambiente, com fundamento na ideia de qualidade de vida. As políticas federais de planejamento
42. No início da década de 1970, o Ipea começou a desenvolver trabalhos sobre as dinâmicas urbanas e regionais voltados para o subsídio de políticas públicas.

43. Francisconi era o responsável pela implementação dessa política, por sua função como Secretário Executivo da Comissão Nacional de Regiões Metropolitanas e Política Urbana (CNPU) da Secretaria de Planejamento da Presidência da República (Seplan/PR), entre os anos de 1974 e 1978 . Cf. Francisconi; Souza (1976).

44. Motta (2011, p. 12).

45. Marly Rodrigues; Tourinho (2017, p. 356). 
46. No caso de São Paulo, no âmbito do órgão de preservação estadual, os estudos de tombamento de cidades históricas iniciaram-se na gestão de Ruy Ohtake, em 1978, em consonância com a política federal de turismo e preservação de bens tombados nos centros históricos. No Condephaat foi elaborado o Programa de Núcleos e Cidades Históricas que se desenvolveu até meados da década seguinte. Dele faziam parte os centros históricos de Iguape, Cananeia, Iporanga, Itu, Bananal, São Luiz do Paraitinga, Santana de Parnaíba e São Sebastião; as decisões sobre a seleção de bens e os limites do que era considerado "histórico" seguiram métodos relacionados com a percepção dessa porção da cidade como objeto único e isolado das demais. Ressalte-se que, em meados da década de 1980, essa metodologia há muito era alvo de críticas no plano internacional, embora fosse concomitante à aplicação de outras metodologias renovadas, que partiam da percepção do meio ambiente e levavam em conta o significado social dos bens. Não havia, contudo, a normatização de critérios a serem considerados na análise e seleção de bens, o que contribuía para a incompreensão de parte da sociedade quanto aos procedimentos e importância da preservação.

47. Não se pretende neste trabalho aprofundar sobre as origens do conceito de "patrimônio ambiental urbano", mas, sim, indicar seus princípios conceituais básicos e as relações entre os campos do planejamento e da preservação, fundamentais para o seu entendimento. Para um maior detalhamento sobre sua origem, trajetória conceitual e correspondência com os enunciados do debate internacional, cf. Rodrigues; Tourinho (2017). Sobre o PCH, além de Corrêa (2012), cf. o dossiê de balanço sobre o Programa, após 40 anos de sua criação, nos Anais do voltadas para a preservação e expressas no Programa de Cidades Históricas (PCH), concebido sob a coordenação da Seplan/PR, entre 1973 e 1979 - quando migrou para o âmbito da Secretaria do Patrimônio Histórico e Artístico Nacional (Sphan) -, apostaram no patrimônio cultural como alavanca para o desenvolvimento regional. Tais políiticas foram contempladas no Plano Nacional de Desenvolvimento Urbano, em consonância com posições internacionais, como aquelas manifestas nas Normas de Quito, conforme abordado anteriormente. ${ }^{46} \mathrm{~A}$ percepção do ambiente urbano ganhava protagonismo nas políticas públicas urbanas e de patrimônio. ${ }^{47}$

A política federal de desenvolvimento urbano teria um rebatimento direto no planejamento estadual de São Paulo. Sua discussão foi introduzida na políitica urbana estadual durante o governo de Paulo Egydio Martins (1975-1979), no âmbito da Secretaria de Economia e Planejamento do Estado de São Paulo (SeplanSP), sob a direção do seu titular, o arquiteto Jorge Wilheim.

Após a realização, em 1975, de um diagnóstico que mostrava o crescimento do processo de interiorização da economia paulista, e seu impacto na paisagem das cidades, a Seplan-SP lançou, em 1978,48 o Programa de Preservação e Revitalização do Patrimônio Ambiental Urbano, em convênio com o lpea e a CNPU. Uma vez mais, se firmaria uma parceria entre essas instituições no desenvolvimento de planos e/ou programas urbanos, desta vez no âmbito estadual. ${ }^{49}$

O referido programa foi elaborado em clara consonância com as políicas federais que pretendiam implantar um sistema integrado de planejamento, buscando dar respostas aos desequilíbrios regionais do país, com base nas teses do II PND de que o impressionante aumento da população urbana estava acarretando "sérios problemas de congestionamento, superpopulação e polvição, em detrimento da qualidade de vida, do equilíbrio social" ${ }^{50}$ Ressaltava-se que o desenvolvimento não é um processo apenas de natureza econômica, mas também cultural, estabelecendo-se, assim, relações com a dimensão da cultura.

A estreita relação entre as iniciativas federal e estadual estava assegurada, inclusive, pelo importante papel assumido pela geógrafa Maria Adélia de Souza na formulação dessas políticas, pois tinha sido coordenadora, junto a Jorge Guilherme Francisconi, da Política Nacional de Desenvolvimento Urbano, no início da década de 1970, tendo coordenado, também, o referido programa estadual em São Paulo. ${ }^{51}$

O Programa de Preservação e Revitalização do Patrimônio Ambiental Urbano surgia, então, como resultado das preocupações com a qualidade de vida afetada pelo acelerado crescimento urbano, que impactava também os valores culturais da sociedade: "antes o ritmo mais lento era paralelo à incorporação de novos valores do modo de vida", sendo crucial "orientar o desenvolvimento urbano 
de tal forma que o mesmo não continue a destruir um dos componentes substanciais da cultura de qualquer povo: seus elementos construtivos, suas maneiras de ser" ${ }^{52}$

Nessa direção, definia-se o patrimônio ambiental urbano como "um dos fatores determinantes do nível de qualidade de vida da população", 53 sendo sua preservação, revitalização e valorização tarefas ineludíveis.

Havia, então, uma clara percepção de que, apesar das diferenças de cada cidade ou localidade, o processo de industrialização no estado de São Paulo imprimia uma mesma marca em seu conjunto: a transformação da paisagem urbana, resultado de uma "sociedade em afã de progresso a custo de qualquer sacrifício cultural". ${ }^{54}$ Criticava-se, assim, um tipo de desenvolvimento urbano que podia, de fato, ser claramente destrutivo:

A atuação conjunta desses fatores - especulação imobiliária sem controle; pressões advindas da imposição de um sistema viário capaz de comportar o crescente número de automóveis; e, ainda, persistência de uma falta de tradição generalizada no que concerne à conservação de bens culturais - configurou num curto espaço de tempo aquilo que se convencionou chamar simplesmente de "destruição do Patrimônio Ambiental Urbano". 55

programa de preservação desse patrimônio justificava-se, assim, pela urgente necessidade de sua defesa, o que pressupunha a existência de uma ameaça: a da renovação urbana:

Preservação e Renovação têm sido encaradas como antagônicas em virtude do próprio dinamismo da sociedade: a renovação só pode se processar sobre um espaço já urbanizado, portanto portador de algum patrimônio, sem se entrar por ora no mérito de seus valores estéticos. ${ }^{56}$

A renovação desenfreada era entendida como um imperativo econômico e, ao mesmo tempo, como um processo predatório, que deveria ser repensado, pois "acarreta transformações físicas, econômicas e simbólicas que favorecem pequenos grupos sociais em detrimento dos antigos moradores, quando, ao contrário, deveria ocasionar uma revitalização de velhos bairros desprovidos de equipamentos coletivos" ${ }^{5}$. Era evidente a influência da experiência de recuperação do centro histórico da cidade de Bolonha, no final da década de 1960 e início dos anos 1970, que se fundamentava na permanência dos habitantes locais, de baixa renda, que ali viviam.

caráter inovador do programa revelava-se tanto em suas definições conceituais quanto nos instrumentos propostos para sua aplicação. No intuito de superar
Museu Paulista (Dossiê O PCH..., 2016).

48. Ainda que lançado em 1978, Rodrigues (2000, p. 60) indica que o Programa já estava elaborado em meados de 1976, conforme ofício enviado pela Seplan-SP ao Condephaat.

49. De acordo com a Seplan-SP (1978), também foram realizadas, no processo de desenvolvimento do referido Programa, reuniões com as Secretarias de Cultura, Ciência e Tecnologia; dos Negócios Metropolitanos e de Esportes e Turismo.

50. Seplan-SP (1978, p. 3).

51. Além da geógrafa, Ricardo Uchôa Alves Lima esteve à frente do Programa em São Paulo, e seu gerenciamento esteve a cargo de Eduardo Yázigi, que, desde então, seguiu pesquisando o tema do patrimônio ambiental urbano.

52. Seplan-SP, op. cit., p.15.

53. Ibid., p. 41.

54. Ibid., p. 13

55. Ibid., p. 15.

56. Seplan-SP (1978, p.16).

57. Ibid., p. 21. 
58. Ibid., p. 36-37.

59. Emplasa (1979, [s. p.])

60. Rodrigues; Tourinho (2017, p. 360). a clássica noção de patrimônio histórico e artístico, o programa avançava no reconhecimento de outros valores, definindo o patrimônio ambiental urbano como o conjunto de "espaços (que transcendem a obra isolada) caracterizadores da cidade devido a seu valor histórico, social, cultural, formal, técnico ou afetivo", sempre associados às relações sociais que neles têm lugar, afirmando, assim, que o "Programa não se preocupa com a mera preservação de edificações, mas com a trama de interações que the confere vitalidade e importância, transformando-os num Patrimônio vivo". 58 Nessa direção, criticava a insuficiência do tombamento, propondo, para a preservação do patrimônio, instrumentos de distinta natureza: de pesquisa, pedagógicos e de divulgação, administrativos e políticos, financeiros e legais.

○ tema do patrimônio ambiental urbano era, também, objeto de interesse de outras instâncias da esfera de planejamento em São Paulo, que não apenas a Seplan, sendo discutido nos âmbitos metropolitano e municipal. A Empresa Metropolitana de Planejamento da Grande São Paulo S.A. (Emplasa), então recémcriada, em maio de 1975, e vinculada à Secretaria de Negócios Metropolitanos, assumia, no âmbito da constituição de um Sistema de Planejamento, uma função afinada aos princípios do planejamento federal, tendo realizado algumas ações, nos anos de 1978 e 1979, relacionadas ao patrimônio ambiental urbano, com o objetivo de "contribuir nas discussões dos principais problemas que afetam a população e as condições de vida urbana na Grande São Paulo". 59 Em 1978, promoveu um debate sobre o tema, em que participaram representantes da área de preservação do patrimônio e da área do planejamento metropolitano e municipal. De acordo com Rodrigues e Tourinho (2017), esses representantes:

[...] em suas manifestações, expressaram a diversidade de concepções de patrimônio, da mais conservadora, baseada na valoração estética e arquitetônica dos bens, àquela que, a partir de critérios antropológicos, sociológicos e históricos, buscava a síntese teórica do conceito em discussão. 60

No âmbito municipal, é suficientemente conhecido o contexto em que foi realizada a primeira listagem de edificações de interesse histórico e paisagístico na cidade de São Paulo na primeira metade da década de 1970, pelo órgão municipal de planejamento. Na ausência de uma instituição voltada para a proteção do patrimônio, a Coordenadoria Geral de Planejamento (Cogep) inicia, em 1974, a identificação de imóveis e áreas de caráter histórico ou de excepcional valor artístico, cultural e paisagístico - a partir de estudo realizado pelos arquitetos Carlos Lemos e Benedito Lima de Toledo -, que seriam classificadas na legislação de zoneamento como zonas especiais de preservação, conhecidas como Z8-200. 
Essa proteção tinha como base a ideia de se preservar as características urbanas e ambientais dessas zonas, influenciada pela experiência francesa dos secteurs sauvagardés, da Lei Malraux, de 1962, a partir da identificação de "manchas", em que se situavam bens culturais significativos. ${ }^{61}$ Ainda que a definição da Z8-200 indique o caráter "excepcional" dos bens de interesse de preservação e não utilize a expressão "patrimônio ambiental urbano", já aparecem, na identificação dessas manchas, alguns dos princípios norteadores do seu reconhecimento.

Contudo, já no final dos anos 1970, Ulpiano Bezerra de Meneses reclamava do fato de que o conceito de patrimônio ambiental urbano - ainda que tenha surgido para superar as restrições de expressões então em voga como "patrimônio cultural" ou "patrimônio artístico, histórico" - se prestava, ele também, a "alguns equívocos e a muita ambiguidade". ${ }^{2}$ Para ele, o equívoco inicial era o fato de que:

[...] patrimônio ambiental urbano não era "uma lista acumulativa de bens" presentes nos espaços e a serem considerados no planejamento, mas "um fato social" complexo, que incluía a consideração de representações (ou símbolos) urbanos, uma vez que neles incluem-se "valores, legitimações, explicações, lógica interna, implícita ou explicita, aspirações e assim por diante" (EMPLASA, 1979, p. 24).63

Esta não foi a interpretação adotada nos trabalhos de identificação do patrimônio ambiental urbano, prevalecendo uma perspectiva de leitura da cidade fundamentada principalmente nos seus aspectos materiais. Rodrigues ${ }^{64}$ relata que, no início de 1977, em ofício enviado pela Seplan ao Condephaat, Maria Adélia de Souza, coordenadora da Ação Regional daquela Secretaria, informava que o Programa de Preservação e Revitalização do Patrimônio Ambiental Urbano tinha sofrido pequenas alterações e que o conceito passava a "definir também aspectos sócio-culturais [sic] que impregnam todas as edificações, mesmo as de caráter recente". ${ }^{65}$ Em seguida, Rodrigues menciona a reação negativa de Lemos:

O Programa, de fato, recebera nova versão duramente criticada por Carlos Lemos que, embora declarando-se partidário do conceito de patrimônio ambiental urbano, julgava ser ela excessivamente enfática nos aspectos sociais. "Esse patrimônio deve ser encarado mais sob o enfoque material - deve ser ligado, o nome assim indica, ao ambiente, ao meio físico, ao espaço urbano, ao espaço arquitetônico", a "elementos tangíveis", pois, considerava o arquiteto, os objetivos da preservação eram as marcas dos homens e não quem presentemente as usufruía ou produzia. ${ }^{60}$
61. Cf. Rodrigues (2001)

62. Meneses (1978, p. 45).

63. Rodrigues; Tourinho (2017, p. 361).

64. Rodrigues (2000, p. 6061).

65. Souza (1977, apud Rodrigues, 2000, p. 60-61).

66. Rodrigues (2000, p. 61). 
67. Crispim (2016, p. 122123).
Apesar das diferentes leituras do conceito, fica evidente que o patrimônio histórico tinha passado a ser incluído na gestão da cidade no Brasil, surgindo, no campo do planejamento econômico e territorial, e no da preservação, a noção de patrimônio ambiental urbano, correlacionando as questões urbanas, culturais e ambientais, pretendendo-se superar a visão de valor excepcional do monumento isolado e englobar os bens culturais comuns, cotidianos, do contexto urbano, integrando o passado à dinâmica social do presente. Termos como "paisagem" e "ambiente" entravam, assim, para o vocabulário das políticas públicas urbanas.

O estudo do caso de São Paulo contribui para a compreensão dos caminhos do conceito de patrimônio ambiental urbano, por ter sido objeto de discussões e programas em distintas esferas de governo durante a década de 1970 e ter sido divulgado na década de 1980 pelos órgãos de preservação do patrimônio. Com efeito, após as experiências da Seplan, Emplasa e Cogep, aqui relatadas, que promoveram o debate e/ou divulgação dessas questões, o conceito de patrimônio ambiental urbano logo abandonaria o âmbito das políticas urbanas, e entraria na pauta dos órgãos estadual e municipal de preservação em São Paulo. Nessa direção, cabe indagar e analisar as formas e sentidos da aplicação desse conceito nas duas esferas de atuação.

\section{O ESTADO DE SÃO PAULO, ENTRE A NATUREZA E A CULTURA}

André Franco Montoro, advogado e político de grande experiência legislativa, participou ativamente da resistência parlamentar à ditadura civil-militar e, com o restabelecimento das eleições diretas para os governos estaduais, foi eleito e empossado governador de São Paulo, em março de 1983, com mandato até março de 1987. Nesse período, ampliou-se a aplicação do tombamento no reconhecimento e proteção de grandes áreas de importância ambiental, ganhando destaque a atuação do Conselho de Defesa do Patrimônio Histórico, Arqueológico, Artístico e Turístico do Estado de São Paulo (Condephaat), o que, em grande parte, se deveu ao geógrafo e professor Aziz Ab'Sáber, que ali atuou, nas décadas de 1970 e 1980, como conselheiro e, por um curto período, como presidente do conselho.

Segundo Crispim, ${ }^{67}$ desde a década de 1970, mais exatamente em 1973, com a abertura do processo de tombamento do Maciço da Jureia, localizado em Iguape, ao sul do estado de São Paulo, a discussão sobre o patrimônio paisagístico cresceu no Condephaat, abrangendo a "natureza, cultura e meio ambiente no âmbito 
do patrimônio paulista", trazendo "novos elementos para a prática patrimonialista" e se tornando uma maneira sistemática de salvaguarda das "áreas naturais".

As tensões próprias de qualquer ação preservacionista revelam conflitos de interesse e a permanência de traços forjados no passado, que compõem o imaginário social; entre eles, a ideia de progresso que leva a classificar a proteção do poder público sobre bens culturais como algo pretérito e oposto ao desenvolvimento.

Ainda que susceptível ao contexto político administrativo, verifica-se a grande potencialidade da aplicação do tombamento, como o exemplo da Reserva do Morro Grande em 1978. Atendendo à pressão de um movimento organizado pelos moradores de Caucaia do Alto, em Cotia, nas proximidades de São Paulo, que contestava um projeto do governo paulista para implantação de um aeroporto que destruiria a Reserva do Morro Grande - importante área florestal e de mananciais - , o Condephaat abriu o processo de tombamento e logrou sustar esse empreendimento.

Assim, incluíram-se, aos valores considerados pelos técnicos, aspectos geomorfológicos que seriam associados à temática do planejamento territorial e do turismo. A introdução desses valores levou, em 1985, ao tombamento da Serra do Mar. Ação polêmica, foi apoiada pelo governo Franco Montoro, uma vez que se tratava de uma atitude pioneira de proteção e contraponto à devastação, então em curso, de áreas da natureza. A aplicação do tombamento a uma área tão vasta e diversa se tornaria um diferencial do Condephaat em relação às práticas preservacionistas até então desenvolvidas no país.

Pouco antes, em 1982, o Condephaat enfrentara um difícil período que incluiu a oposição da opinião pública à sua atuação no caso da derrubada de casas que ainda compunham o conjunto original da Avenida Paulista, promovida pelos proprietários após o vazamento da informação de que elas seriam objeto de tombamento. Em consequência, o Conselho se demitiria coletivamente, sendo interinamente substituído sob a presidência do geógrafo Aziz Ab'Sáber, por um curto período, entre novembro de 1982 e março de 1983. Com a nomeação dos novos conselheiros, ele seria sucedido pelo antropólogo Antonio Augusto Arantes Neto.

A gestão Montoro foi um período de diversificação da especialidade profissional dos presidentes do Conselho, fator de grande importância na condução das decisões de proteção a bens culturais, uma vez que essas se fundamentam em argumentos que incluem conhecimentos técnicos e valores moldados - em parte considerável -, a partir de distintos campos do saber. ${ }^{68}$

Desde sua criação em 1968, o Condephaat contava com representações da Universidade de São Paulo (áreas de Pré-História e História), às quais, dez anos depois, foram acrescidas as de Geografia e Arquitetura. Em 1985, a representação
68. Na gestão do governador Orestes Quércia (19871991), sucessor de Montoro, essa diversidade se manteria, limitada, porém, pelo esmaecimento do sentido democratizante vigente no período anterior e por atitudes de cerceamento da função do Condephaat, o que feriu as perspectivas de políticas de patrimônio que vinham se delineando. 
69. Em defesa da... (1984, p. 18).

70. O Condephaat, sensível a essa mobilização, abriu processo de tombamento do edifício em 1975, tombando-o definitivamente em junho de 1976 universitária se ampliou para as demais universidades públicas paulistas e para outras áreas de conhecimento: a Antropologia e a Sociologia. Refletia-se, assim, a ampliação do entendimento do patrimônio; a expansão dos estudos, discussões e práticas estava rompendo a ideia naturalizada de patrimônio, dele como algo dado, o que abriu a sua percepção como uma construção social atinente à cultura em seu sentido amplo. Ao mesmo tempo, potencialmente, abriam-se maiores possibilidades do conselho tornar-se um espaço de debates sobre o patrimônio como vetor de memória, esse fator estruturante da sociedade. Percebia-se, também, com maior nitidez a necessidade de a construção social do patrimônio ser alvo de uma política de Estado, duradoura e promotora de resultados a médio e a longo prazos.

Nesse sentido, contribuíram marcantes mobilizações sociais. Uma delas, em defesa de áreas verdes, ocorreu, em 1984, em torno de uma casa tombada como bandeirista no bairro do Itaim Bibi, em São Paulo, e revela a dissonância entre os valores atribuídos pelo Condephaat e o sentido que a área assumira para os moradores locais. Em 1982, a área fora tombada considerando-se o valor da edificação nela contida, uma vez que se tratava de uma construção em taipa de pilão, antiga técnica construtiva. Porém, o sentido dado à área pelos moradores do bairro era reivindicar a implantação de um parque público, o que foi explicitado nas faixas por eles portadas em suas manifestações públicas: "verde é vida, defenda o Parque do ltaim". 69 Parque que não se concretizou.

No mesmo período, outra mobilização de mesmo teor, organizada pelos moradores da Vila Mariana, visando a criação de um parque no terreno da Casa Modernista projetada por Gregori Warchavchik, logrou concretizar-se, ainda que os valores em que se baseou o tombamento do Condephaat (1984) fossem os arquitetônicos.

Em 1986, por solicitação da Sociedade de Amigos do Jardim Europa e Paulista (Sajep), o Condephaat tomou uma posição inédita, ao tombar os bairros paulistanos dos Jardins América, Europa, Paulista e Paulistano considerando seu valor ambiental, além dos históricos e urbanísticos.

Havia dez anos, a importância dos afetos para a preservação do patrimônio, campo onde se situa a memória, manifestou-se na mobilização em torno da antiga Escola da Praça, a Caetano de Campos, ameaçada de demolição para dar lugar à Estação República do Metrô. ${ }^{70}$ Pelos bancos da escola haviam passado algumas personalidades destacadas, formadoras de opinião que, unidas a um grande número de outros ex-alunos e professores, ganharam a imprensa e levaram a empresa construtora a buscar soluções técnicas para manter o edifício, projeto original de Ramos de Azevedo, sem prejuízo da Estação. A instituição estadual começara a confrontar-se com o desafio de garantir o direito à cidade e à memória. 
Pode-se considerar que, no cotidiano do órgão paulista de preservação, o reconhecimento da importância da memória e do patrimônio construído, representação de enorme potencial mnemônico, se deu em 1983 por ocasião de um seminário promovido pelo Condephaat, durante o qual o tema foi apresentado.

Esse seminário traria novas perspectivas para o primeiro corpo técnico próprio do Condephaat, composto apenas de profissionais de duas áreas de conhecimento, Arquitetura e História. A esse somou-se outro, a então denominada "equipe de áreas naturais", que, a partir de 1982, por cinco anos, atuaria atendendo aos casos de tombamento e intervenções em bens relacionados ao meio ambiente. Dela faziam parte dois antropólogos, cujos pontos de vista influíram na concepção de patrimônio dos demais profissionais e cuja atuação foi decisiva para a análise e melhoria da relação entre as ações do Condephaat e a população.

Essa relação foi uma das preocupações centrais da gestão de Antonio Augusto Arantes. $\bigcirc$ distanciamento propiciava a criação de situações críticas, de agressão a bens tombados e desconsideração das determinações do órgão, especialmente no caso de obras que acabavam por romper o equilíbrio dos conjuntos tombados. A partir de uma pesquisa de recorte antropológico realizada na cidade de Santana do Parnaíba, cujo centro histórico foi tombado em 1982, verificou-se que a reação local derivava da própria metodologia adotada, na qual a população era mantida alheia à seleção dos bens inclusos no tombamento e considerava que aqueles, para ela, mais representativos não haviam sido destacados para receber a proteção do poder público. $\bigcirc$ resultado e o debate do tema entre os técnicos possibilitariam uma melhor aproximação em casos futuros, embora não resultasse na definição ou adoção de metodologia específica para os casos de estudos de tombamentos de centros históricos, na qual se considerasse a participação das populações locais.

A relevância que o tema "preservação" vinha assumindo na sociedade e a complexidade a ser considerada nas análises realizadas pelos órgãos públicos, para decisão sobre tombamento e intervenções, motivaram Arantes a promover, em julho e agosto de 1983, o referido seminário, que contou com a participação de professores universitários de diferentes áreas e com profissionais atuantes na área de preservação. ${ }^{71}$ Composto de duas partes, Cultura, Patrimônio e Preservação e Problemas Metodológicos, ele resultou em considerável ampliação do universo conceitual dos técnicos.

Pela primeira vez em encontros de profissionais debateram-se os vínculos entre memória e patrimônio, e o significado de comemorações e bens materiais para a coesão de grupos sociais. Esses temas despertaram a atenção dos técnicos para a importância dos aspectos simbólicos envolvidos em sua prática profissional e para a importância da consideração do saber antropológico em seu campo de atuação.
71. Parte desse seminário foi publicado na obra organizada por Arantes (1984). 
Observa-se que, de modo geral, durante a década de 1980, o engajamento dos técnicos constituiu um dos fatores que, aliado às perspectivas delineadas pela especialidade de presidentes do Conselho e à vontade política de governantes, reforçou a importância da proteção pública da memória e do meio ambiente como demandas sociais e aspectos integrantes da cultura; portanto, segundo a definição da $\mathrm{ONU}$, dos próprios direitos humanos.

Um exame comparativo da lista de bens tombados pelo Condephaat na década de 1980 com as de anos anteriores - onde há abundância de residências urbanas senhoriais, sedes de fazenda e igrejas católicas, entre as quais estavam ausentes "estilos arquitetônicos" como o eclético e o moderno -, permite concluir que se procedeu à diversificação de bens protegidos com o acréscimo de unidades fabris, bairros, edifícios de arquitetura moderna, jardins e monumentos. Procedeuse, também, à democratização do reconhecimento público de valores culturais de segmentos sociais e étnicos, como simbolicamente representa o tombamento do terreiro Axé llê Obá, na cidade de São Paulo, ocorrido em 1990.

Porém, manteve-se ausente a cidade, tomada no conjunto como artefato cultural e lugar de memórias, pleno de referências culturais. Não foi, portanto, totalmente satisfeita a reivindicação de melhor qualidade do meio ambiente, formulada na década de 1980. Em favor dela foram criados, posteriormente, instrumentos de grande força legal, como o Estatuto da Cidade, propiciadores da ação conjugada entre setores públicos responsáveis pelo planejamento e pela preservação. Resta enfrentar mais esse desafio.

\section{A CIDADE DE SÃO PAULO, ENTRE A RENOVAÇÃO E A PRESERVAÇÃO}

Um desafio que começou a se delinear na década de 1970, quando o acentuado crescimento das metrópoles brasileiras se tornara uma questão preocupante, como vimos anteriormente. Esse crescimento se manifestará, na década de 1980, no embate entre renovação urbana e preservação do patrimônio na cidade de São Paulo, o que viria a ser um elemento importante nas políticas municipais de patrimônio. Aliadas a essas questões, a então ampliação do conceito de patrimônio se traduzirá em experiências inovadoras de tentativas de aproximação com o campo do planejamento, de valorização das memórias sociais e de interação com a sociedade no âmbito do órgão municipal de preservação. 
Desde o final da década de 1970, o Departamento de Patrimônio Histórico da Cidade de São Paulo (DPH), ${ }^{72}$ órgão de preservação criado em 1975 - que só em 1977 passa a ter um corpo técnico permanente -, realiza, em conjunto com o então órgão de planejamento municipal, a Coordenadoria Geral de Planejamento (Cogep), estudos visando à identificação, para posterior proteção, dos bens culturais situados na área de influência imediata da linha Metrô Leste, em fase de construção. O trabalho realizado, intitulado Patrimônio Ambiental Zona Metrô Leste (1978), procedeu à delimitação de manchas que atendiam à definição de "áreas com características ambientais significativas para a compreensão do processo histórico de desenvolvimento urbano da região". ${ }^{73}$ Nele já se encontrava a noção de patrimônio ambiental urbano, e, apesar de não ter logrado seu objetivo de proteção das áreas identificadas com interesse de preservação, devido à força dos interesses econômicos envolvidos, esse trabalho terá uma significativa influência nos inventários posteriores realizados pelo DPH.

A perda de referências históricas, provocada pelos processos de renovação urbana, nesse caso, da zona leste, relacionados a questões de mobilidade e a interesses imobiliários, já constituía, nesse momento, uma das preocupações que iria orientar as ideias e práticas de preservação do patrimônio em São Paulo. O que será uma constante em uma cidade em que a cultura do novo, relacionada a uma produção predatória de cidade, se impõe com grande força, principalmente, a partir da década de 1920.

Desde o final dos anos 1970, o arquiteto Murillo Marx, então diretor do $\mathrm{DPH}$, acalentava a ideia da realização de um inventário sistemático na cidade de São Paulo, iniciado por aquele realizado na zona leste. ${ }^{74}$ Com esse objetivo, foram realizados trabalhos de levantamento nas áreas do entorno do antigo Mercado de Santo Amaro (1978/79) e de inventário - em escala bem menos ampla do que o da zona leste - do outeiro da Freguesia do Ó (1979).

A partir de 1983, considerando essas primeiras experiências e o debate conceitual em voga, o DPH desenvolveu uma metodologia e iniciou a realização de um programa de inventários sistemáticos de bairros paulistanos. Essa ação, denominada Inventário Geral do Patrimônio Ambiental, Cultural e Urbano de São Paulo (lgepac-SP), fundamentava-se, basicamente, na noção de patrimônio ambiental urbano, e pretendia se integrar ao processo de planejamento da cidade:
72. No âmbito do DPH, a unidade responsável pelos trabalhos técnicos de inventário e tombamento era, então, a Divisão de Preservação, a que nos referimos, neste trabalho, como DPH.

73. Baffi (2006, p 171)

74. Cf. Andrade (2012).

Além dos já tradicionalmente consagrados pelo seu valor histórico, artístico, arqueológico, turístico ou arquitetônico, compreende-se como patrimônio ambiental e cultural passíveis de preservação os elementos partícipes do processo cultural da sociedade. 
75. DPH (1986, p. 47).

76. Cf. DPH (1986).

77. Ibid. (1986, p. 24).

78. Cf. Tourinho; Rodrigues (2016).

79. Cf. Baffi (2006).

80. Ibid.
São considerados não só os monumentos isolados ou casos de excepcional valor mas, principalmente, elementos representativos enquanto: pluralidade de ocorrência na paisagem, estruturação de valor ambiental, caracterização de tipos de agenciamentos urbanos, ou seja, aqueles elementos cuja valorização está na manifestação repetitiva na cidade, além daqueles de valor eminentemente afetivo para a comunidade. ${ }^{75}$

Detalhou-se uma metodologia de inventário que tinha como objetivo identificar as manchas urbanas mais significativas dos bairros paulistanos, abrangendo duas etapas de trabalho. Na primeira, seria identificada a conformação geral do bairro, por meio da leitura da paisagem - contemplando aspectos morfológicos, tipológicos, usos, marcos visuais, entre outros -, bem como estudos de evolução urbana e de legislação. Na segunda etapa, seriam detalhados os estudos das manchas definidas na primeira fase de trabalho, indicando-se os imóveis a serem preservados. ${ }^{76}$

A primeira etapa do inventário contemplava, também, a "coleta de depoimentos de antigos moradores e líderes de comunidade local", 77 utilizando os métodos da história oral. No entanto, esses depoimentos parecem ter sido utilizados mais como complementação da informação histórica, do que como forma de conhecimento das percepções e representações dos moradores do bairro. ${ }^{78}$ Nessa direção, um levantamento mais aprofundado - que enfatizava a pesquisa sociológica e os registros orais - foi realizado no inventário do bairro da liberdade, pelo DPH, na metade dos anos 1980, sem, contudo, chegar a resultados efetivos de preservação de referências dessa área, naquele momento. ${ }^{79}$ Esse tipo de pesquisa também foi realizado no Igepac Bela Vista, mas parece ter sido desenvolvida de forma separada do levantamento arquitetônico e urbano, que focou a legibilidade da paisagem do bairro, critério que predominou na definição dos elementos a serem preservados.

Com base na metodologia do Igepac-SP, realizaram-se, na década de 1980, os inventários dos bairros da Liberdade (1983), da Bela Vista (1984-85), da Barra Funda (incompleto, 1985) e do Centro Velho (1987); bem como o préinventário, de caráter simplificado, dos bairros de Santa Cecília, Higienópolis e Consolação (1986). No final dessa década e início de 1990, foram realizados os inventários do Centro Novo (1988, 1991), Campos Elíseos (1 990), Consolação (1990), Vila Buarque (1991-93) e Ipiranga, nas áreas próximas ao Parque da Independência (1 992). ${ }^{80}$ Alguns deles foram utilizados como base para propostas de tombamento, quando passou a ser efetivamente aplicada essa figura de proteção do patrimônio, criada em 1985, no âmbito da Prefeitura de São Paulo.

Contudo, a realização do inventário sistemático não se consolidou e, apesar da incorporação pelo DPH das noções que então se discutiam, parte substancial de sua prática ficou atrelada ao conceito de patrimônio ambiental 
urbano mais focado na leitura da cidade, que predominou sobre aquele definido por Ulpiano Bezerra de Meneses, que privilegiava a importância do reconhecimento das representações urbanas suscitadas por esse tipo de patrimônio. Com efeito, desde a década de 1960, os estudos de legibilidade urbana referentes à paisagem e à imagem da cidade, como aqueles realizados por Gordon Cullen e Kevin Lynch, produziam grande influência nos conceitos e metodologias de identificação dos elementos caracterizadores do tecido urbano, tanto no campo do planejamento urbano, quanto no do patrimônio cultural. No final dos anos 1970, Carlos Lemos enfatizava esse aspecto do patrimônio ambiental urbano:

[...] é fundamentalmente composto de uma grande massa de elementos típicos, normais, comuns, cotidianos que, eles sim, representam alguma coisa no contexto urbano. Os bens históricos e artísticos quase todos são exceção. Percebemos que um dos interesses maiores quanto à conservação do patrimônio ambiental urbano é a conservação da inteligibilidade do espaço urbano, a compreensão da cidade, a leitura da cidade. ${ }^{81}$

Ainda assim, o desenvolvimento de uma metodologia de identificação do patrimônio significou um avanço nas ações de proteção realizadas na década de 1980. A proposta de se compreender a cidade a partir do bairro guardava o agudo entendimento dessa parte da cidade como unidade primária, caracterizada por elementos que conferem identidade a esse território. Uma unidade de estudo que foi se perdendo no tempo, hoje substituída pela abstrata entidade administrativa da subprefeitura.

A metodologia de identificação de manchas - fossem elas bairros ou perímetros -, com interesse de preservação, também teria lugar, em 1984, na publicação conjunta entre a Emplasa e a Secretaria Municipal de Planejamento (Sempla, antiga Cogep), Bens Culturais Arquitetônicos no Município e na Região Metropolitana de São Paulo.

Não se pode desprezar, ainda, na década de 1980, o contexto político das gestões municipais em que ocorriam as discussões sobre o patrimônio e a cidade. O Igepac-Bela Vista, por exemplo, que tinha sido desenvolvido durante a gestão Mario Covas (1983-1985), tinha definido, de forma inédita, um perímetro urbano significativo para proteção, com a indicação de imóveis a serem enquadrados como zonas de interesse de preservação, as chamadas Z8200. Contudo, a mudança de gestão para a administração Jânio Quadros (1986-1988) adiaria a proteção dessa área, que só começará a se efetivar na gestão Luíza Erundina (1 989-1992), quando o inventário foi revisto e atualizado, dando ensejo à abertura do processo de tombamento do bairro em 1990.
81. Lemos (1979, apud Emplasa, 1979, p. 9). 
82. O episódio suscitou inclusive uma edição especial da revista Espaço \& Debates (1986) sobre o projeto de Jânio e seu impacto no centro da cidade, reunindo uma série de textos escritos por autores de diferentes disciplinas, como a cientista política Maria Tereza Sadek, o geógrafo Milton Santos, os arquitetos Cândido Malta e Regina Meyer, e os cientistas políticos Paulo Sérgio Pinheiro e Maria da Glória Gohn, que discutiam, justamente, o conflito entre preservação e renovação, que era percebido com grande força naquele momento.
A gestão Jânio Quadros também posterga - desta vez sem qualquer mudança, até o momento - a ideia de um conselho municipal de preservação do patrimônio com significativa participação da sociedade civil, fruto de um desejo de ampla representatividade social nessa instância deliberativa, tal como se estabelecia na Lei Municipal n 10.032, de 27 de dezembro de 1985, que criou - Conselho Municipal de Preservação do Patrimônio Histórico, Cultural e Ambiental da Cidade de São Paulo (Conpresp). Os artigos dessa lei, que versavam sobre a composição do conselho, com representantes das universidades, de entidades culturais e associações comunitárias e, ainda, do Condephaat - além de representantes de associações de classe e do poder público -, foram vetados e alterados, resultando na Lei $n^{\circ}$ 10.236, de 16 de dezembro de 1986.

A postura política dessa gestão contrariou o contexto nacional, no campo da preservação do patrimônio, que, nesse momento, assistia à criação de conselhos municipais de preservação com ampla representação social e técnica. No Rio de Janeiro, cria-se o Conselho Municipal de Proteção do Patrimônio Cultural (CMPC), 1980; em Porto Alegre, a Equipe do Patrimônio Histórico e Cultural, 1981; em Belo Horizonte, o Conselho Deliberativo do Patrimônio Cultural Municipal (CDPCM-BH), 1984; em Salvador, a Fundação Gregório de Matos, 1986; e no Recife, a Diretoria de Preservação do Patrimônio Cultural. Na região metropolitana de São Paulo, cria-se o Conselho Municipal do Patrimônio Histórico e Cultural de São Bernardo do Campo, 1984.

Além disso, o prefeito Jânio Quadros cria uma Secretaria Extraordinária de Patrimônio, enfraquecendo a atuação técnica do DPH e apenas no final de 1988 nomeará o primeiro colegiado do Conpresp, objetivando o tombamento de alguns poucos bens pertencentes à própria Prefeitura.

Alheio às questões de memória, ambiente e qualidade de vida, as políticas urbanas de Jânio apostavam nas ideias de renovação urbana, representadas pelos projetos de reurbanização do bairro central de Santa Ifigênia e, depois, de reurbanização da margem esquerda do Rio Tietê, entre a Lapa e a Penha, encomendados ao arquiteto Oscar Niemeyer e outros. Os ambiciosos projetos não foram realizados, mas a polêmica foi significativa, produzindo um grande debate sobre renovação versus preservação: ${ }^{82}$

A discussão se organizava, então, nos mesmos termos daquela que se tinha travado nos países europeus e nos Estados Unidos entre os anos 1960 e 1970. Também se recorria ao exemplo da cidade de Bolonha, na Itália (1964-69), como a experiência mais inovadora de intervenção urbana, por ter conseguido articular o desenvolvimento urbano e a proteção do patrimônio cultural, ressaltando a participação da população neste processo. Este aspecto 
era particularmente importante para as ânsias democráticas relacionadas ao momento que vivia o Brasil, sintetizadas nas seguintes palavras de [Paulo Sérgio] Pinheiro (1986:1 19): "num momento de reinvenção da democracia a população das cidades tem de se transformar em sujeito das definições dos projetos, especialmente num ano da Constituinte". ${ }^{83}$

O debate entre renovação e preservação se fez presente, também, na gestão da prefeita Luiza Erundina (1989-1992). Nessa administração, o lgepac Bela Vista, realizado entre 1983 e 1985, foi objeto de revisão e atualização com o objetivo de fornecer subsídios aos participantes do Concurso Nacional de ldeias para a Renovação e Preservação do Bexiga, promovido pela prefeitura, através da Empresa Municipal de Urbanização (Emurb), entre 1989 e 1992, para aquela área. Essa iniciativa fez parte de uma inovadora ação no sentido de se estabelecer, então, uma ponte entre a preservação do patrimônio e o planejamento urbano.

A revisão desse lgepac seguiu os mesmos critérios do inventário inicial quanto ao reconhecimento dos bens culturais caracterizadores do patrimônio ambiental urbano, estando o DPH preocupado com propostas de renovação urbana que viessem a fazer tabula rasa do Bexiga, alertando para o potencial do ambiente urbano do bairro, com os suportes físicos de sua identidade cultural. $\bigcirc$ valor ambiental e a leitura da cidade continuavam sendo os alicerces da fundamentação teórica para a preservação do patrimônio do bairro:

Partiu-se do princípio de se conservar, ao máximo, a legibilidade urbana daquela região. Para tanto procurou-se preservar o maior número possível de conjuntos arquitetônicos e de outros elementos da paisagem urbana. Obviamente, os bens excepcionais foram contemplados, mas o que nos preocupou principalmente foi o casario anônimo, testemunha dos modos de organização do espaço urbano e das várias etapas e formas de evolução daquela parte da cidade, onde não é o valor intrínseco dos imóveis considerados que tem interesse e, sim, o efeito do conjunto. No intuito de manter a legibilidade referida, foram identificadas construções de valor ambiental. ${ }^{84}$

Apesar das críticas sobre a italianização da memória do Bexiga, esse momento, possibilitou a convergência de discussão sobre a renovação e a preservação no bairro e foi particularmente rico em debates, com ampliação da participação social no Concurso de Ideias.

Nessa gestão, da prefeita Erundina, é possível perceber uma mudança com relação à cultura, que passa a ter novos enfoques, visões e participação de grupos sociais na área de museus, arquivos e preservação, claramente perceptíveis nas administrações da Secretaria Municipal de Cultura, assumida pela filósofa Marilena Chavi, a partir de 1989, e pela historiadora Déa Ribeiro
83. Tourinho (2004, p. 301).

84. Campos (1992 apud Departamento do Patrimônio Histórico, 1992, [s. p.]). 
85. Em 1992, a relevância da relação entre preservação e memória refletiu-se no tombamento do conjunto das instalações da Companhia Brasileira de Cimento Portland Perus (CBCPP) pelo Conpresp. A Resolução $n^{\circ}$ 27/Conpresp/92, referente ao ato jurídico de reconhecimento público, contemplou a "relevância da memória dos trabalhadores da CBCPP enquanto símbolo de determinada forma de organização, luta e resistência dos trabalhadores", os Queixadas, que, a partir da década de $\mathbf{1 9 5 0 ,}$ organizaram várias greves $\mathrm{e}$ movimentos em defesa da melhoria de suas condições de trabalho e remuneração.

86. Rodrigues (2000, p. 73).

87. DPH (1985, p. 18)

88. Parte das palestras e resultados desse Congresso foi publicada em DPH (1992).
Fenelon, na diretoria do DPH e presidência do Conpresp. A relação entre cultura e cidadania é contundentemente defendida nesse governo municipal, que se pretende participativo e comprometido com mudanças. ${ }^{85}$

A década de 1980 foi, também, um momento em que se organizaram fóruns de discussão sobre o patrimônio. Em 1981, o I Encontro Nacional de Arquitetos sobre a Preservação dos Bens Culturais - Arquimemória, na cidade de São Paulo, reuniu profissionais e estudantes de vários campos do conhecimento:

\begin{abstract}
objetivo era definir uma política de preservação de bens culturais a ser defendida pelos arquitetos e refletiu o clima reinante durante o processo de abertura política, no qual segmentos organizados da sociedade procuravam defender direitos e estabelecer canais que possibilitassem maior participação nas decisões de interesse público. Considerando o patrimônio parte da memória da sociedade brasileira, os participantes criticaram a excessiva centralização das decisões e dos instrumentos de preservação nas mãos do Estado, o que acabava por favorecer interesses políticos particulares e por alijar a população das decisões. ${ }^{86}$
\end{abstract}

Verifica-se, claramente, a contestação ao discurso hegemônico do estado sobre a preservação do patrimônio no Brasil; a participação social viria a ser uma bandeira da sociedade civil organizada.

Em 1985, o DPH realiza a $1^{\text {a }}$ Semana do Patrimônio Histórico da Cidade de São Paulo, sob as gestões de sua diretora, Suzanna Cruz Sampaio, e do Secretário Municipal de Cultura, Gianfrancesco Guarnieri. Entre as várias palestras e eventos realizados durante a Semana, alguns deles versaram, justamente, sobre o ambiente urbano, entre eles a exposição "Rua Florêncio de Abreu - Programa de Valorização da Área Central", projeto do DPH visando a sensibilização dos comerciantes para melhorias do ambiente local. No encerramento da Semana, foi lido um documento aprovado em plenário, sendo muito significativa, dentre as seis moções apresentadas, aquela que pedia "a transformação da cidade em espaço que privilegie a qualidade de vida da população, que a especulação imobiliária corrói gradativamente" ${ }^{87}$ Mencionou-se, ainda, a boa expectativa que havia em relação à futura Assembleia Constituinte, que já se organizava, e que acabou resultando na tão importante Constituição Federal de 1988, na qual se destacam os artigos 215 e 216 , que reconceituaram o patrimônio cultural brasileiro.

Após a promulgação dessa Constituição, em agosto de 1991, o DPH promoveu um Congresso Internacional sobre Patrimônio Histórico e Cidadania, um debate que apenas se iniciava entre nós. ${ }^{88}$ No Documento Final da plenária do congresso afirmou-se o direito à memória como uma dimensão do direito fundamental 
da cidadania, e que não "tem sido devidamente considerada nas diretrizes das políticas públicas voltadas para a preservação do patrimônio histórico e cultural" ${ }^{89}$

\section{DIREITOS, CIDADE E MEMÓRIA, ELOS EM CONSTRUÇÃO}

Os casos aqui abordados, das instituições paulista e paulistana de proteção ao patrimônio cultural, apontam para a importância dos sistemas democráticos e da consciência dos direitos sociais para a construção da memória da sociedade e obtenção de melhor qualidade de vida.

Em ambas as esferas se verificou, desde a década de 1980, a ampliação de conceitos operacionais que possibilitaram a diversificação do universo de representações culturais, embora não se alcançasse o escopo implícito na definição constitucional de 1988, pela qual o patrimônio resulta do conjunto de bens que são referências culturais dos diversos segmentos formadores da sociedade.

A participação direta da sociedade na definição do que será considerado patrimônio cultural restringe-se, em geral, às solicitações encaminhadas aos órgãos públicos competentes; mesmo limitado, na medida em que crescem a consciência e as reivindicações de lugares sociais e do direito à memória, essa forma vem tendo um papel essencial na democratização das decisões de tombamento. Apenas no início da década de 1990, intensificou-se a utilização do direito à memória como argumento para as solicitações de tombamento e em avaliações técnicas.

Até mesmo depois da extensão da proteção do poder público federal aos bens imateriais, ocorrida no ano de 2000,90 a construção do patrimônio privilegia a cultura material, e, nesse âmbito, os espaços edificados, sendo ou não referências culturais, mas sem que ainda sejam considerados como parte constituinte do território, que é o lugar de desenvolvimento das atividades cotidianas, carregado de significados e de memórias, na concepção tão bem defendida pelo geógrafo Milton Santos. ${ }^{91}$

$\bigcirc$ quadro que envolve o atendimento ainda incompleto da reivindicação de qualidade do meio ambiente, formulada na década de 1980, é complexo e conformado, além de outros, por fatores que implicam a concepção excludente de sociedade e de direitos sociais. Entre esses, é sintomática a atuação da administração pública que, de modo geral, é exercida sem a integração de setores cujas funções são complementares, como o planejamento territorial e a preservação.

Não obstante na segunda metade da década de 1970 se verificassem esforços para unir a atuação desses dois setores por meio de um conceito único,
89. DPH (1992, p. 229).

90. Decreto no $3.551 / 2000$ estabelece o registro como instrumento legal de proteção de bens culturais de natureza imaterial. No município de São Paulo, a proteção está baseada na Lei no 14.406 , de 21.5.2007 e no Estado de São Paulo, no Decreto no 57.439, de 2011.

91. Cf. Santos (2008). 
- de patrimônio ambiental urbano, a sua adoção no campo da preservação acabou por não explorar a potencialidade agregadora de valores simbólicos e mnemônicos nele contida às ações de melhoria das condições ambientais.

A incompreensão dessa qualidade, ou a dificuldade em operacionalizá-la, resultou na manutenção de avanços apenas pontuais das práticas de proteção ao patrimônio. Não se constituiu, assim, um conjunto definidor de experiências capazes de caracterizar uma política pública de preservação, ainda que não imbricada a outras práticas sociais, mas, sim, efetivadora de direitos sociais. Tampouco se verificou na década de 1980 qualquer disposição em estruturar uma política de preservação, ainda que não de Estado, pelo menos de governo.

No momento atual, é significativa a retomada das discussões em torno do conceito de patrimônio ambiental urbano. Mais do que em 1980, vivemos a destruição, quer dos valores sociais, quer do meio ambiente, objeto que envolve disputas de territórios. Entre os desafios de ações que valorizam certas áreas urbanas, impõe-se manter as populações em seus lugares originais; sem isso, acentua-se o desrespeito aos direitos à memória e à cidade e perpetua-se a imensa desigualdade que caracteriza nossa sociedade. 


\section{REFERENCIAS}

FONTES IMPRESSAS

DEPARTAMENTO DO PATRIMÔNIO HISTÓRICO (São Paulo). Boletim do Departamento do Patrimônio Histórico, São Paulo, no 2, 1985.

LIVROS, ARTIGOS E TESES

ANDRADE, Paula Rodrigues. O patrimônio da cidade: arquitetura e ambiente urbano nos inventários de São Paulo da década de 1970. 2012. 153 f. Dissertação (Mestrado) - Faculdade de Arquitetura e Urbanismo, Universidade de São Paulo, São Paulo, 2012.

ARANTES, Antonio Augusto (org.). Produzindo o passado. Estratégias de construção do patrimônio cultural. São Paulo: Brasiliense, 1984.

BAFFI, Mirthes. O Igepac-SP e outros inventários da Divisão de Preservação do DPH: um balanço. Revista do Arquivo Municipal, São Paulo, n. 204, p.169-191, 2006.

CESARI, Carlo (org.). Il passato per um nostro avvenire. Ferrara: Comune di Ferrara, 1980.

CHAUI, Marilena. Cidadania Cultural O Direito à Cultura. São Paulo: Editora Fundação Perseu Abramo, 2006.

CORRÊA, Sandra Rafaela Magalhães. 2012. O Programa de Cidades Históricas (PCH): por uma política integrada de preservação do patrimônio cultural - 1973/1979. 2012. Dissertação (Mestrado) - Faculdade de Arquitetura e Urbanismo, Universidade de Brasília, Brasília, 2012.

CRISPIM, Felipe Bueno. Entre a geografia e o patrimônio: estudo das ações de preservação das paisagens paulistas pelo Condephaat (1969-1989). São Bernardo do Campo (SP): EduFABC, 2016.

CUNHA FILHO, Francisco Humberto; BOTELHO, Isaura; SEVERINO, José Roberto (org.). Direitos Culturais. Salvador, 2018. Vol.1. Coleção Cultura e Pensamento.

CURY, Isabelle (org.). Cartas patrimoniais. Rio de Janeiro: Iphan, 2000. 
DPH - DEPARTAMENTO DO PATRIMÔNIO HISTÓRICO (São Paulo). Inventário geral do patrimônio ambiental e cultural: metodologia. São Paulo: DPH, 1986. Cadernos do Igepac-SP 1.

DPH - DEPARTAMENTO DO PATRIMÔNIO HISTÓRICO (São Paulo). O direito à memória: patrimônio histórico e cidadania. São Paulo: DPH, 1992.

DOSSIÊ O PCH, Programa de Cidades Históricas: um balanço após 40 anos. Anais do Museu Paulista: História e Cultura Material, São Paulo, vol. 24, nº 1, jan./abr. 2016.

EM DEFESA DA CASA BANDEIRISTA. O Estado de S. Paulo. São Paulo, OESP, 21 out. 1984. p. 18.

EMPLASA - Empresa Metropolitana de Planejamento da Grande São Paulo S.A. Unidade de Ação Comunitária. Comunidade em debate: patrimônio ambiental urbano. São Paulo: Emplasa, 1979. Caderno de divulgação do debate Patrimônio Ambiental Urbano em São Paulo.

FRANCISCONI, Jorge Guilherme e Maria Adélia A. de Souza. Politica nacional de desenvolvimento urbano: estudos e proposições alternativas. Brasília: Ipea, 1976.

LEFEBVRE, Henri. O direito à cidade. São Paulo: Centauro, 2001.

LEMOS, Carlos. Participação em debate. In: EMPLASA. Comunidade em debate: patrimônio ambiental urbano. São Paulo: Emplasa, 1979, p. 8-12. Caderno de divulgação do debate "Patrimônio Ambiental Urbano em São Paulo", promovido pela Emplasa em 27 set. 1978.

MAGNANI, José Guilherme Cantor. Santana de Parnaíba: memória e cotidiano. In: MAGNANI, José Guilherme Cantor. Da periferia ao centro: trajetórias de pesquisa em Antropologia Urbana, p. 67-69. São Paulo: Terceiro Nome. Coleção Antropologia Hoje. 2012.

MARCHESAN, Ana Maria Moreira. Movimentos sociais, direitos humanos e patrimônio cultural. In: SOARES, Inês Virginia Prado; CUREAU, Sandra. Bens culturais e direitos humanos. São Paulo: SESC São Paulo, 2015. p. 317-331.

MENESES, Ulpiano Toledo Bezerra de. Participação em debate. In: Emplasa. Comunidade em debate: Patrimônio Ambiental Urbano. São Paulo: Emplasa, 1979, p. 20-33. Caderno de divulgação do debate "Patrimônio Ambiental Urbano em São Paulo", promovido pela Emplasa em 27 set. 1978.

MENESES, Ulpiano Toledo Bezerra de. Patrimônio ambiental urbano: do lugar comum ao lugar de todos. CJ Arquitetura, São Paulo, no 19, p.45-46, 1978. 
MOTTA, Diana Meirelles da. Prefácio. In: PEREIRA, Rafael Henrique Moraes; FURTADO, Bernardo Alves (Orgs.). Dinâmica urbano-regional: rede urbana e suas interfaces. Brasília: Ipea, 2011. p. 11-17.

PAZZINI, Bianca; Sparemberger, Raquel Fabiana Lopes. O direito à memória e à identidade no Brasil: perspectivas de efetivação da preservação do patrimônio cultural. Revista do Instituto do Direito Brasileiro, Lisboa, Ano 3, $\mathrm{n}^{\circ}$ 6, 2014.

RODRIGUES, Marly. Imagens do passado. A instituição do patrimônio em São Paulo, 19691987. São Paulo: Unesp; Imprensa Oficial do Estado; Condephaat; FAPESP, 2000.

RODRIGUES, Marly; TOURINHO, Andréa de O. Patrimônio, espaço urbano e qualidade de vida: uma antiga busca. Oculum Ensaios, Campinas (SP), v. 14, n. 2, p. 349-366, mai.-ago., 2017. Dossiê Patrimônio Cultural Ibero-Americano.

SANTOS, M. A Natureza do Espaço: Técnica e Tempo, Razão e Emoção. São Paulo: Edusp, 2008.

SEPLAN-SP - Secretaria de Economia e Planejamento do Estado de São Paulo. 1978. Programa de Preservação e Revitalização do Patrimônio Ambiental Urbano. São Paulo: Ipea. Trabalho elaborado em convênio com IPEA/CNPU. Documentos, 10.

SNM/EMPLASA/SEMPLA - Secretaria de Estado dos Negócios Metropolitanos. Empresa Metropolitana de Planejamento da Grande São Paulo S.A. Secretaria Municipal do Planejamento. Bens Culturais Arquitetônicos no Município e na Região Metropolitana de São Paulo. São Paulo: SNM / Emplasa / Sempla, 1984.

TAVOLARI, Bianca. Direito à cidade: uma trajetória conceitual. Novos Estudos n. 104, mar. 2016 p. 93-107.

TOURINHO, Andréa de O. Do Centro aos centros: bases teórico-conceituais para o estudo da centralidade em São Paulo. 438 f. 2004. 153 f. Tese (Doutorado) - Faculdade de Arquitetura e Urbanismo, Universidade de São Paulo, São Paulo, 2004.

TOURINHO, Andréa de O.; RODRIGUES, Marly. Patrimônio ambiental urbano: uma retomada. Revista CPC, São Paulo, v. 22, p. 70-91, jul./dez. 2016.

VARINE, Hugues de. As raízes do futuro: o patrimônio a serviço do desenvolvimento local. Porto Alegre: Medianiz, 2013.

VARINE-BOHAN, Hugues de. A experiência Internacional. Notas de aula 12.8.1974. São Paulo: FAU-USP; Iphan. 
Artigo apresentado em 1/1/2020. Aprovado em 22/4/2020.

\section{(cc) BY}

All the contents of this journal, except where otherwise noted, is licensed under a Creative Commons Attribution Licens 